osądu, biorącego pod uwagę nie tylko teologiczne punkty widzenia, ale też argumenty rozumowe. Niektóre $z$ takich partykularnych zasad mogą okazać się mocno związane z kulturą, w której powstały. Zamiast wierności literze trzeba wtedy próbować odnaleźć intencję, która przyświecała ich powstaniu i kierując się nią sformułować nowe zasady postępowania, odpowiednie do zmienionych czasów i kultury $^{27}$.

Również radykalne zasady Kazania na Górze, jak pacyfizm czy zakaz sądzenia, nie dadzą się bezpośrednio użyć jako elementu państwowego kodeksu prawnego i mogą być na poziomie społeczeństwa zastosowanie jedynie w sposób intencjonalny. Nie oznacza to jednak, że chrześcijanie powinni zadowolić się stwierdzeniem, że Kazanie na Górze jest w większości niewykonalne. Właśnie na tym polega największe wyzwanie, stojące przed Kościołem naszych czasów, aby świeckiemu społeczeństwu, które nie jest w stanie żyć według zasad Królestwa Bożego ukazać obraz niejako „społeczeństwa kontrastowego” („Kontrastgesellschaft” - G. Lohfink), które jeszcze bardziej wyeliminowałoby ze swojego życia przemoc, wyzysk i nierówność socjalną, które starałoby się przynajmniej zbliżyć do ideału nakreślonego przez Kaznodzieję na Górze Błogosławieństw.

Nie sposób jest wyczerpująco rozwiązać sformułowanej w tytule niniejszego opracowania alternatywy. Kazanie na Górze pozostanie na zawsze profetyczną prowokacją, nie dającą się zamknąć w jakimś kodeksie postępowania. Ale też pozostanie ono na zawsze wyzwaniem dla każdego chrześcijanina, który szuka odpowiedzi na pytanie, jak iść w dzisiejszym świecie w ślady Mistrza z Nazaretu.

Augsburg

KS. MARIAN MACHINEK MSF

Ks. Jan Józef Janicki

\title{
PASCHA - CENTRUM ROKU LITURGICZNEGO STAREGO I NOWEGO LUDU BOŻEGO
}

W nauczaniu soboru Vaticanum II i Kościoła posoborowego zostało wielokrotnie podkreślone znaczenie misterium paschalnego Chrystusa, które stanowi centralne wydarzenie całej historii zbawienia, a w konsekwencji centrum roku liturgicznego i całego życia

${ }^{27}$ Zob. H. S c h ü r m a n n, Die Frage nach der sittlichen Verbindlichkeit der neutestamentlichen Wertungen und Weisungen. Eine Skizze, [w:] Prinzipien christlicher Moral, hrsg. J. Ratzinger, Einsiedeln 1975, s. 38. 
chrześcijańskiego nowego Ludu Bożego, Kościoła ${ }^{1}$. Chrystus Pan bowiem dokonał dzieła odkupienia człowieka i doskonałego uwielbienia Boga, „które zapowiadały wielkie sprawy Boże spełnione wśród ludu Starego Testamentu”, „przez paschalne misterium swojej błogosławionej Męki, Zmartwychwstania i chwalebnego Wniebowstąpienia" (KL 5). Przez to misterium Chrystus „umierając, zniweczył naszą śmierć, i zmartwychwstając, przywrócił nam życie"; "swoją śmiercią wybawił nas od śmierci, a Jego zmartwychwstanie jest zadatkiem naszego zmartwychwstania”; ,zniweczył moc grzechu, odnowił całe stworzenie i nam przywrócił utracone życie”; "przez ofiarę swojego ciała na krzyżu dopełnił On ofiary Starego Przymierza i oddając się za nasze zbawienie sam stał się Kapłanem, Ołtarzem i Barankiem ofiarnym². Apostołowie zostali posłani przez Chrystusa Pana „nie tylko po to, aby głosząc Ewangelię wszystkiemu stworzeniu, zwiastowali, że Syn Boży swoją śmiercią i zmartwychwstaniem wyrwał nas z mocy szatana $\mathrm{i}$ uwolnił od śmierci oraz przeniósł do królestwa Ojca, lecz także po to, aby ogłaszane dzieło zbawienia sprawowali przez Ofiarę i sakramenty, stanowiące ośrodek całego życia liturgicznego" (KL 6). Liturgia zatem, „przez którą... dokonuje się dzieło naszego Odkupienia" (KL 2), stanowi szczyt, „do którego zmierza działalność Kościoła” i jest źródłem, „z którego wypływa cała jego moc” (KL 10).

Kościół, nowy Lud Boży, zdąża do wyrażenia i zrealizowania w swoim życiu, uobecnianego w liturgii, misterium paschalnego. Chodzi o to, aby wierni włączeni w misterium Śmierci i Zmartwychwstania Chrystusa, obumarli dla grzechu i upodobnieni do swego Pana, ,już nie żyli dla siebie, lecz dla Tego, który za nich umarł i zmartwychwstal” (2 Kor 5, 15). „Ponieważ śmierć Chrystusa na krzyżu i Jego zmartwychwstanie stanowią treść codziennego życia Kościoła i zapowiedź wiecznej Paschy, pierwszym zadaniem liturgii jest niestrudzone wprowadzanie nas na otwartą przez Chrystusa paschalną drogę, na której człowiek godzi się umrzeć, aby mieć życie wieczne"3. To dzieło dokonuje się przez wiarę i sakramenty wiary

${ }^{1}$ Zob. KL 5.6.61; ONRLiK 1.18; Kongregacja Kultu Bożego, List okólny o przygotowaniu $i$ obchodzeniu świq̨ paschalnych, n.1.38.77; por. B. $\mathrm{N}$ e u n$\mathrm{h}$ e u s e r, Il mistero pasquale "culmen et fons" dell'anno liturgico, RiL 72(1975) 151-164; J. G r z e ś k o w i a k, Liturgia dziś, Katowice 1982, 19n; M. A u g é, Teologia dell'anno liturgico, [w:] Anamnesis. Introduzione storicoteologica alla Liturgia. 6. L'anno liturgico, Genova 1989, 25n; J. J a n i c k i, Eucharystia-centrum $i$ wypetnienie misterium paschalnego, RBL 46(1993) 148-156; J. J a n i c k i, Misterium paschalne Chrystusa centralnym wydarzeniem życia Kościoła, RBL 49(1996) 236-248; i inne.

2 1.2.4.5. prefacja wielkanocna (Mszal Rzymski dla diecezji polskich, Poznań $\left.1986,37^{*}, 38^{*}, 40^{*}, 41^{*}\right)$. 
czyli przede wszystkim przez chrzest („przez który ludzie zostają wszczepieni w paschalne misterium Chrystusa: z Nim współumarli, współpogrzebani i współzmartwychwstali, otrzymują ducha przybrania za dzieci, w którym wołamy: Abba, Ojcze!" (KL 6) i Najświętsze Misterium Eucharystii (powierzona umiłowanej Oblubienicy Kościołowi pamiątka Męki i Zmartwychwstania Zbawiciela (por. KL 47), wokół którego skupiają się pozostałe sakramenty i sakramentalia (które czerpią swoją moc z paschalnego misterium Męki, Śmierci i Zmartwychwstania Chrystusa (por. KL 61) oraz rok liturgiczny, w którym rozwija się misterium paschalne Chrystusa w Kościele („każdego tygodnia Kościół obchodzi pamiątkę Zmartwychwstania Pańskiego w dniu, który nazwał Pańskim, a raz do roku czci je także z Jego błogosławioną Męką na Wielkanoc, w to swoje największe święto" KL 102) ${ }^{4}$. Takie rozumienie prawdy wiary sprawiło, że Kościół od czasu, kiedy w dzień Zesłania Ducha Świętego ukazał się światu, „nigdy nie zaprzestawał zbierać się na odprawianie paschalnego misterium... sprawując Eucharystię, w której uobecnia się zwycięstwo i triumf Jego śmierci" (KL 6). Eucharystia jako ośrodek całego życia chrześcijańskiego tak Kościoła powszechnego jak i lokalnego, w sposób szczególny gromadzi cały Lud Boży i sprawia, że wierni, swoim życiem, wyrażają i ujawniają innym „misterium Chrystusa i rzeczywistą naturę prawdziwego Kościoła" (KL 2).

Sobór Watykański II ukazując istotę wspólnoty Kościoła sprawującego liturgię, określa Kościół, jako lud święty, zjednoczony i zorganizowany pod zwierzchnictwem biskupów, a o czynnościach liturgicznych mówi, iż nie są one czynnościami prywatnymi, ale należą do całego „Ciała Kościoła, uwidaczniają je i na nie oddziałują” (KL 26). Kościół ukazuje się światu przede wszystkim w pełnym i czynnym uczestnictwie całego Ludu Bożego w liturgii, a zwłaszcza w Eucharystii; chodzi tu o zbawcze działanie, „przez które Zbawiciel realizuje nasze przejście ze śmierci do życia, z niewoli do wolności, od grzechu do świętości” ${ }^{\circ}$. Zbawcze działanie Chrystusa „Z Jego szczytowym dopełnieniem, dokonanym raz na zawsze $\mathrm{w}$ misterium paschalnym, staje się - przez liturgię - fundamentalną wartością chrześcijańskiego życia", misterium paschalne Chrystusa stanowi centralne

${ }^{3} \mathrm{~J}$ a n $\mathrm{P}$ a w e 1 II, List Apostolski $i$ dwudziesta piata rocznice ogłoszenia Konstytucji soborowej „Sacrosanctum Concilium” o świętej liturgii (04. 12.1988), n. 6.

${ }^{4}$ Zob. Święta Kongregacja Obrzędów, Instrukcja o należytym wykonywaniu Konstytucji o świętej liturgii (26.09.1964), n. 6.

${ }^{5}$ W. Ś w i e r z a w s k i, Dynamiczna „Pamiqtka Pana”. Eucharystyczna anamneza Misterium Paschalnego i jego egzystencjalna dynamika, Kraków $1980,67$.

${ }^{6}$ Tamże. 
wydarzenie życia Kościoła ${ }^{7}$. Ta wiara Kościoła nakazywała wspominać i uobecniać, „przez cały rok”: „zbawcze dzieło Syna Bożego” „całe misterium Chrystusa” - „misteria Odkupienia” (por. KL 102), których momentem centralnym jest misterium paschalne Chrystusa. Dlatego też, wokół tajemnicy paschalnej, zajmującej centralne miejsce w historii zbawienia, koncentruje się całoroczne życie Kościoła; „misterium paschalne stanowi bowiem fundament, na którym wznosi się misterium Kościoła, realizujące się w różny sposób, ale przede wszystkim i najpełniej w misterium liturgii. Kościół i liturgia są po prostu kontynuacją odkupienia dokonanego $\mathrm{w}$ misterium paschalnym. (...) Bóg chciał, by dzieło zbawienia zrealizowane w misterium paschalnym Chrystusa, było kontynuowane w Kościele i przez Kościół. (...) Kościół zrodzony w misterium paschalnym od pierwszej chwili swego historycznego objawienia się w dniu zesłania Ducha Świętego sprawuje liturgię i „od tego czasu Kościół nigdy nie zaprzestał zbierać się na odprawianie paschalnego misterium" (KL 6) ${ }^{8}$. Z biegiem roku zatem, Kościół, obchodząc misteria Odkupienia, „otwiera bogactwa zbawczych czynów i zasług swojego Pana, tak że one uobecniają się ... w każdym czasie, aby wierni zetknęli się z nimi i dostąpili łaski zbawienia" (KL 102). A ponieważ dzieła odkupienia ludzi i doskonałego uwielbienia Boga dokonał Chrystus Pan przez paschalne misterium swojej Męki, Zmartwychwstania i Wniebowstąpienia (por. KL 5), dlatego rok liturgiczny nowego Ludu Bożego - Kościoła koncentruje się wokół Paschy Chrystusa, Jego misterium paschalnego, które Kościół celebruje (sprawuje) w cyklu rocznym, tygodniowym i dziennym ${ }^{9}$. W ten sposób, z biegiem roku Kościół przeżywa jakby w syntezie całą historię zbawienia skoncentrowaną wokół Paschy Chrystusa; dlatego wspólczesna teologia nazywa rok liturgiczny: sakramentem całej historii zbawienia ${ }^{10}$. Obecny czas Kościoła

${ }^{7}$ Por. uwagi na ten temat poczynione w art. J. J a n i c k i, Misterium paschalne Chrystusa..., art. cyt., 236-248.

${ }^{8} \mathrm{~J}$. G r z e ś k o w i a k, Liturgia dziś..., dz. cyt., 19 n.

${ }^{9}$ Papież Paweł VI w Piśmie Apostolskim z 14 lutego 1969 r., zatwierdzającym ogólne normy roku liturgicznego i nowy ogólny kalendarz rzymski, powołując się na naukę Soboru Watykańskiego II stwierdził, że obchód misterium paschalnego ma najważniejsze znaczenie w liturgii chrześcijańskiej, a obchodzenie to dokonuje się w ciągu dni, tygodni i całego roku.

${ }^{10}$ Zob. S. C z e r w i k, Odnowa liturgii roku kościelnego, Kielecki Przegląd Diecezjalny 46(1970)7. Autor wyjaśnia, że „termin 'sakrament' jest tu użyty w tradycyjnym znaczeniu biblijno-patrystycznym na określenie jakiegoś znaku widzialnego, pod którego osłoną ukrywa się i jest nam udzielana pewna rzeczywistość niewidzialna i nadprzyrodzona. Właśnie cykl niedziel, uroczystości, świąt i okresów liturgicznych, jest tym znakiem - sakramentem aktualizującym i uobecniającym wydarzenia zbawcze, które się raz tylko dokonały w konkretnych warunkach czasowo-przestrzennych" (tamże). 
jest przedłużeniem działania misterium paschalnego Chrystusa na całą ludzkość żyjącą w kolejnych epokach historii i w różnych miejscach świata; „przedłużeniem dokonującym się poprzez liturgię Ofiary i Sakramentów, sprawowaną w ramach roku kościelnego"11.

Paschę Chrystusa, która stanowi szczytowy punkt i źródło dynamizmu całej historii świętej i która jest dzisiaj centrum roku liturgicznego nowego Ludu Bożego - Kościoła, należy widzieć w świetle wszystkich zbawczych działan Boga, które dokonywały się w historii zbawienia, a przede wszystkim pośród Ludu Bożego Starego Przymierza, dla którego święto Paschy - największa doroczna uroczystość, było - jak obecnie jest chrześcijańska „Nowa Pascha” - anamnezą aktualizującą zbawcze działanie Boga ${ }^{12}$.

\section{ŚWIETO PASCHY - CENTRUM ROKU U LUDU BOŻEGO STAREGO PRZYMIERZA-IZRAELA}

Co roku, w dniu wiosennej pełni księżyca, Izrael obchodził święto Paschy, które było nie tylko pamiątką - anamnezą wydarzeń, które zadecydowały o losach Izraelitów jako narodu wybranego: „przejścia” Boga wśród swego ludu, wyjścia z Egiptu - „domu niewoli”, „przejścia” przez Morze Czerwone, zawarcia przymierza i objęcia w dziedzictwo (po długoletniej wędrówce przez pustynię) przyobiecanej ziemi „mlekiem i miodem płynącej" ${ }^{13}$. Świętowanie Paschy stało się nie tylko pamiątką (zikkarôn) wielkich dzieł Bożych dokonanych w historii, zbawczego wydarzenia jako faktu minionego, ale żywą aktualizacją zbawczej Paschy; „przez tę kultową „pamiątkę” zbawienie czasów minionych staje się rzeczywistością aktualną, teraźniejszą. (...) Jednostka nie odczuwa żadnej różnicy między sobą a przodkami, gdy chodzi o udzielone dobra i odtworzenie zdarzeń przez kult. (...) Izraelita ufał, że błogosławieństwo Boże jest odpowiedzią na „wspomnienie” kultyczne: „na każdym miejscu, gdzie każę ci wspominać Imię moje, przyjdę do ciebie i będę ci błogosławił" (Wj 20, 24). (...) W każdym pokoleniu należy się uważać jakby za tego, który wyszedł z Egiptu ${ }^{14}$.

Coroczna Pascha Izraela przeżywana była nie tylko jako minione wydarzenie zbawcze, ale jako kolejny moment działania Boga o nie-

${ }^{11}$ Tamże, 6. 121.

12 Zob. A. J a n k o w s k i, Biblijna teologia przymierza, Katowice 1985,

${ }^{13}$ Por. A. J a n k o w s k i, Biblijna teologia..., dz. cyt., 111; S. C z e rw i k, O tej ksiqżce, [w:] L. B o u y e r, Misterium paschalne, Kraków 1973, VII.

${ }^{14}$ A. J a n k ow s k i, Biblijna teologia..., dz. cyt., 110. 
przerwanej dynamice. „Zapoczątkowało ono mianowicie poprzez przymierze synajskie egzystencję Ludu Bożego, wciąż zbawianego przez Jahwe. Według oczekiwań żydowskich kresem Paschy ma być Mesjasz i jego czasy. Stąd więc paschalny obchód żydowski poprzez teraźniejszość sięgał do przyszłości eschatologicznej ... Te trzy wymiary Paschy żydowskiej, nieodłącznej od Wyjścia i zawarcia Przymierza, a więc przeszłość Mojżeszowa, teraźniejszość Izraelowa i przyszłość Mesjaszowa otrzymują w słowach i gestach Jezusa podczas Ostatniej Wieczerzy swoją transpozycję eschatologiczną"15.

Rokrocznie obchodzona przez Izraelitów Pascha jako pamiątka anamneza aktualizująca Wyjście i Przymierze, wędrówkę Ludu Bożego i mesjańską przyszłość - stała się dla ludu wybranego największym świętem ${ }^{16}$. „Dzień ten będzie dla was dniem pamiętnym (zikkarôn) i obchodzić go będziecie jako święto dla uczczenia Pana. Po wszystkie pokolenia - na zawsze w tym dniu świętować będziecie" (Wj 12, 14).

„Nasze dzisiejsze terminy „pamiątka” czy „upamiętnienie”, bo jedno i drugie oznacza grecka anámnesis, mają o wiele mniejszą ekspresję, niż miał dla Hebrajczyków zikkarôn. (...) Dla Izraela wspomnienie kultowe, z ich trzema głównymi świętami: Paschą, Świętem Tygodni i Namiotów, były czymś więcej niż tylko rocznicami. Izrael bowiem rozumiał dzieje tak świata, jak własne, jako serię zbawczych dzieł Boga z tym że minione stanowiły rękojmię dalszej docelowej i zbawczej dynamiki Boga: czas ... w Starym Testamencie jest linearny i zmierza do Mesjasza i Dnia Pana. Przeszłość gwarantuje w ten sposób i teraźniejszość, i przyszłość, jest podwaliną wysiłki i nadziei: „Pamiętaj ... o znakach i cudach, o mocnej ręce i wyciągniętym ramieniu, którym cię wyprowadził twój Bóg Jahwe" (Pwt 7, 19) ... 'Jednostka nie odczuwa żadnej różnicy między sobą a przodkami, gdy chodzi o udzielone dobra i odtworzenie zdarzeń przez kult'. Tak też było ze świętowaniem Paschy, „pamiątką” Wyjścia: „Przez tę kultową 'pamiątkę' zbawienie czasów minionych staje się rzeczywistością aktualną, teraźniejszą"17. „Anamneza paschalna Izraela miała swoją dynamikę: wzmacniała raz zawarte pod Synajem przymierze drogą swoistego uobecnienia"18. „Obchodząc więc Paschę Izraelita uobecniał sobie zbawcze dzieło Wyjścia, głosił Boże miłosierdzie pieśnią uwielbienia ... dziękował i zarazem ufnie błagał o dalszą realną

15 Tamże, 111.

16 Tamże, 121.116.

17 Tamże, 110.

18 Tamże, 117. „Pascha ma charakter zbawczy, to znaczy w sposób dynamiczny, progresywny i skuteczny realizuje zbawczy plan Boży w kolejnych, coraz bogatszych w duchową spuściznę, okresach historii ST". (S. P o t o c k i, Misterium Paschy Starego Testamentu, RBL 41(1988)285). 
pomoc - o dopełnienie Bożych obietnic, włącznie do eschatologicznych"19.

Rytuał Paschy, jako największego ze świąt Izraela, kształtował się poprzez wieki i miał dwa momenty „liturgiczne”: jednym była ofiara składana w świątyni, a drugim uczta-wieczerza paschalna odbywająca się po domach, w rodzinach ${ }^{20}$. „Pascha była do tego stopnia sakralną ucztą wspólnoty narodowo-religijnej Izraela, iż nie mógł w niej brać udziału żaden cudzoziemiec (Wj 12, $43.45 .48 \mathrm{n}$ ). Ten udział był nie tylko przywilejem, ale i obowiązkiem członka Ludu Bożego, gdyż stanowił ponowny znak trwałego przymierza"21.

Historia uroczystości paschalnej Izraela sięga starożytnego święta pasterskiego, agrarnego związanego z kulturą rolniczą ludów osiadłych, uprawiających ziemię, do jakich zaliczał się i Izrael ${ }^{22}$. Początkowo rok hebrajski stanowiły trzy doroczne święta rolnicze: święto przaśników (spożywanie przez siedem dni chleba $\mathrm{z}$ niekwaszonej mąki, w miesiącu wyjścia z Egiptu, Abib), święto żniw (pierwszych zbiorów) i święto zbiorów (na końcu roku) (Wj 23, 14-17 i 34, 18-23). Te starożytne święta pasterskie zostały przekształcone „w uroczystość upamiętniającą wydarzenia, które dały początek ludowi wybranemu: cudowne wyzwolenie $z$ niewoli egipskiej" ${ }^{23}$ i przymierze synajskie, które zapoczątkowało i egzystencję Ludu Bożego ${ }^{24}$. W Księdze Powtórzonego Prawa $(16,1-17)$ w/w święta otrzymują nowe nazwy i stają się świętem: Paschy, Tygodni i Namiotów ${ }^{25}$. Ta zmiana nazw nie była przypadkowa, ale oznaczała zmianę z „rolniczego” spojrzenia na te święta, z płaszczyzny naturalistyczno-kosmicznej (żniwa, zbiory itp.) - na perspektywę „teologiczną” tzn. w stosunku do Boga Stwórcy i Bożych interwencji, które dały początek, poprzez Wyjście - Wyzwolenie z Egiptu i Przymierze Ludowi Bożemu; w ten sposób święta te stały się wyrazem historii zbawienia ${ }^{26}$. I tak:

1) święto przaśników zostaje nazwane świętem Paschy, na wspomnienie „przejścia” (pesah-pascha) Boga wyzwoliciela w Egipcie i cu-

${ }^{19}$ A. J a n k o w s k i, Eucharystia jako "nasza Pascha” (1 Kor 5, 7) $w$ teologii biblijnej Nowego Testamentu, RBL 28(1975)96.

${ }^{20}$ Por. jw., 91.

21 Tamże, $92 \mathrm{n}$.

${ }^{22}$ Por. B. M o k r z y c k i, Droga chrześcijańskiego wtajemniczenia, Warszawa $1983,382 \mathrm{n}$.

${ }^{23} \mathrm{~J} . \mathrm{K}$ u d a s i e w i c z, Pascha, [w:] Stownik teologiczny. 2. Katowice 1989,60 .

${ }^{24}$ Zob. A. J a n k o w s k i, Biblijna teologia..., dz. cyt., 111.

${ }^{25}$ Por. także Kpl 23, 4-36; święta te ponadto miały być celebrowane w Jerozolimie.

${ }^{26}$ Zob. S. M a r s i l i, Teologia liturgica. III. Anno liturgico, Roma 1972, $10 \mathrm{n}$. 
downego wyzwolenia ludu z niewoli oraz przejścia przez Morze Czerwone (zob. Pwt 16, 1-8; Kpł 23, 4-14).

2) Święto żniw staje się świętem Tygodni, siedmiu tygodni po uwolnieniu z Egiptu i otrzymaniu od Boga Prawa- Przykazań na górze Synaj i ogłoszenia Przymierza (to święto ze względu na sumę dni: 7 tygodni $\times 7$ dni będzie nazwane Pentecoste - 50-y dzień „assereth” zakończenie, koniec „wyjścia” (exodus) (zob. Pwt 16, 9-12; Kpł 23, 15-22).

3) Święto zbiorów przekształci się w święto Namiotów, na wspomnienie czasu na pustyni, szczęśliwego czasu przebywania Boga pośród swego ludu (zob. Pwt 16, 13-15; Kpł 23, 33-36).

Jak zatem widać, święta hebrajskie, w ich nazwach i treści, ukazują ścisły związek z największym wydarzeniem historii Ludu Bożego - Izraela: Przejściem Boga, Wyjściem z niewoli i Przymierzem. To wydarzenie zaczyna się świętem Paschy, przedłuża się w święto Tygodni (Pięćdziesiątnica), które wspomina chwalebny moment Przymierza na Synaju, i zamyka się świętem Namiotów („kuczek”), które podkreśla pierwsze doświadczenia po uwolnieniu na pustyni.

Starożytne zatem święta agrarno-naturalistyczne, choć pozostały w „swojej” porze roku (przaśniki-Pascha: wiosna; żniwa-Tygodnie: lato; zbiory-Namioty: jesień), to jednak straciły swoje pierwotne odniesienie do pór roku, a przyjęły - otrzymały znaczenie świąt - „pamiątki" (anamnezy aktualizującej) Bożych interwencji w stosunku do "Swojego ludu wybranego"27. Swięta pozostają, ale przekształca się oraz zmienia ich nazwa i treść: od świąt religijnych o podłożu naturalistycznym do świąt - celebracji o podłożu i treściach soteriologicznych, zbawczych ${ }^{28}$. Święto Paschy aktualizuje pośród Ludu Bożego zbawcze działanie Boga, wznawiające skutki Przymierza ${ }^{29}$.

W ramach liturgicznego roku biblijnego również tydzień hebrajski ulega wpływowi i reformuje się w perspektywie paschalnej. Cotygodniowe święto - szabat otrzymuje znaczenie, które łączy je wprost z uwolnieniem „paschalnym” wyjścia z Egiptu: odpoczynek związany ściśle $\mathrm{z}$ tym dniem, a nakazany $\mathrm{w}$ związku z Bożym dziełem stworzenia („W sześciu dniach bowiem uczynił Pan niebo, ziemię, morze oraz wszystko, co jest w nich, w siódmym zaś dniu odpoczął. Dlatego pobłogosławił Pan dzień szabatu i uznał go za święty (Wj 20, 11); Przez sześć dni będzie się wykonywać pracę, ale dzień siódmy będzie szabatem odpoczynku, poświęconym Panu ... To będzie znak wiekuisty między Mną a Izraelitami, bo w sześciu dniach Pan stworzył niebo i ziemię, a w siódmym dniu odpoczął i wytchnął" (Wj 31, 15.17) - odtąd będzie przypominał zbawczą interwencję Boga, który uwolnił

${ }^{27}$ Tamże, 11 n; zob. A. J a n k o w s k i, Biblijna teologia..., dz. cyt., 121.

${ }^{28}$ Zob. S. M a r s i l i, Teologia liturgica..., dz. cyt., 12.

${ }^{29}$ Zob. A. J a n k o w s k i, Biblijna teologia..., dz. cyt., 121. 
swój Lud od pracy niewolniczej w Egipcie: „Sześć dni będziesz pracował i wykonywał wszelką twą pracę, lecz w siódmym dniu jest szabat Pana, Boga twego. Nie będziesz wykonywał żadnej pracy ... Pamiętaj, że byłeś niewolnikiem w ziemi egipskiej i wyprowadził cię stamtąd Pan, Bóg twój, ręką mocną i wyciągniętym ramieniem: przeto ci nakazał Pan, Bóg twój, strzec dnia szabatu" (Pwt 5, 13-15).

W liturgicznym roku biblijnym, oprócz corocznego święta i tygodnia także dzień otrzymuje szczególne odniesienie do Paschy. Każdy hebrajski dzień charakteryzował się codzienną ofiarą całopalenia, która była rozumiana jako pamiątka największego dnia w historii religijnej Izraela: „To jest ustawiczne całopalenie, które już na górze Synaj składano dla Boga jako miłą woń ofiary spalanej” (Lb 28, 6). Codzienna ofiara całopalenia miała „uwieczniać” ofiarę przymierza złożoną na Synaju, a zatem spełniała rolę ustawicznego odnawiania tego starożytnego i fundamentalnego przymierza, które zostało usankcjonowane właśnie ofiarą na Synaju. Ofiara całopalenia stanowiła rację, dla której Bóg uwolnił swój lud: „A On (Bóg) powiedział: Ja będę z tobą. Znakiem zaś dla ciebie, że Ja cię posłałem, będzie to, że po wyprowadzeniu tego ludu z Egiptu oddacie cześć Bogu na tej górze" (Wj 3, 12; por. Wj 3, 18; 7, 16) ${ }^{30}$.

Jak to zostało w skrócie wyżej ukazane, Izrael - Lud Boży Starego Przymierza obchodził liturgicznie największe wydarzenie swojej historii: Paschę, w wymiarze rocznym, tygodniowym i dziennym.

„A wszystko to przydarzyło się im (=Izraelitom) jako zapowiedź rzeczy przyszłych..." poucza św. Paweł (1 Kor 10, 11). Pascha Izraela ,jest tylko zapowiedzią Paschy, jaka miała się dokonać raz na zawsze w Chrystusie, nowym Adamie i Głowie, i jaka konsekwentnie musi się dokonywać w każdym z członków Ciała aż się dokona w całym Ciele"31. Sobór Watykański II poucza, że Bóg zbawiając ludzi wybrał sobie najpierw „na lud naród izraelski, z którym zawarł przymierze i który stopniowo pouczał, siebie i zamiary woli swojej objawiając w jego dziejach i uświęcając go dla siebie. Wszystko to jednak wydarzyło się jako przygotowanie i jako typ owego przymierza nowego i doskonałego, które miało być zawarte w Chrystusie... Chrystus ustanowił to nowe przymierze, a mianowicie nowy testament we krwi swojej (por. 1 Kor 11, 25), powołując spośród Żydów i pogan lud, który nie wedle ciała, lecz dzięki Duchowi zróść się miał w jedno i być nowym Ludem Bożym. Albowiem wierzący w Chrystusa, odrodzeni (...) z wody i Ducha Świętego (por. J 3, 5n), ustanawiani są w końcu „rodzajem wybranym, królewskim kapłaństwem, narodem świętym, ludem nabytym..., co niegdyś nie był ludem, teraz zaś jest ludem Bożym" (1 P 2, 9n)" (KK 9). Z nauczania soborowego wiemy, że Bóg po-

${ }^{30}$ Zob. S. M a r s i l i, Teologia liturgica..., dz. cyt., 14 n.

${ }^{31} \mathrm{~S}$. C z e r w i k, $O$ tej ksiqzice..., art. cyt., IX. 
stanowił wierzących w Chrystusa zgromadzić w Kościele świętym, „który już od początku świata ukazany przez typy, cudownie przygotowany w historii narodu izraelskiego i w Starym Przymierzu, ustanowiony w czasach ostatecznych, objawiony został przez wylanie Ducha, a w końcu wieków osiągnie swe chwalebne dopełnienie" (KK 2). Jezus Chrystus ustanowił nowy Lud Boży, powołany ze wszystkich narodów, przez śmierć i zmartwychwstanie swoje (por. KK 7); przymierze zatem Boga z całą ludzkością zrealizował Jezus Chrystus, który „lepszego przymierza stał się pośrednikiem” (Hbr 8, 6). „Zawarcie nowego przymierza dokonało się w czasie Ostatniej Wieczerzy jako sakramentalnej antycypacji śmierci i zmartwychwstania Jezusa... Dlatego właśnie Chrystus w słowach ustanowienia Eucharystii nawiązuje wyraźnie do przymierza synajskiego. Słowa: „To Krew moja przymierza” (Mt 26, 28) lub: „To nowe przymierze we Krwi mojej” (Łk $22,20)$ są wyraźnym nawiązaniem do słów Mojżesza wypowiedzianych w momencie zawierania przymierza na Synaju (por. Wj 24, 8). Jezus przez wyraźną aluzję do starego przymierza uczy, że ustanawia nową ekonomię zbawienia w miejsce tej, której pośrednikiem był Mojżesz. Ustanawia Je w czasie uczty paschalnej. (...) Ofiary zwierząt starego przymierza zastępuje ofiara nowa, której krew skutecznie realizuje definitywną jedność między Bogiem a ludźmi. Tajemnica przymierza, czyli tajemnica Boga z ludźmi, osiąga swe ukoronowanie. W ten sposób nowe przymierze łączy się ściśle ze starym, a równocześnie je przewyższa i doskonali; jego pośrednikiem jest bowiem nie Mojżesz, ale Jezus Chrystus" ${ }^{\text {"2 }}$.

\section{PASCHA CHRYSTUSA - CENTRUM ROKU LITURGICZNEGO NOWEGO LUDU BOŻEGO-KOŚCIOŁA}

Nowy Lud Boży - Kościół zrodził się ze zbawczego misterium paschalnego Chrystusa, czyli Jego śmierci i zmartwychwstania. Nowe Przymierze zrealizowało się przez zbawczą śmierć i zmartwychwstanie Jezusa, a dzisiaj uobecnia się w Eucharystii i innych sakramentach, a także w roku liturgicznym. „Sercem Nowego Przymierza jest sprawowana przez Kościół jako nowy Lud Boży Eucharystia"33. Sercem i ośrodkiem całego roku kościelnego jest tajemnica paschalna Chrystusa, będąca źródłem zbawienia dla wszystkich ludzi; poprzez liturgię Eucharystii i sakramentów sprawowanych w ramach roku kościelnego przedłuża się zbawcze działanie misterium paschalnego na całą ludzkość żyjącą w kolejnych epokach historii i w coraz to no-

32 J. K u d a s i e w i c z, Przymierze..., art. cyt., 172 n.

${ }^{33}$ A. J a n k ow s k i, Biblijna teologia..., dz. cyt., 117 n. 
wych miejscach świata ${ }^{34}$. Chrześcijańska „Nowa Pascha”, tak jak Pascha Ludu Bożego Starego Przymierza, staje się anamnezą a k t ua $l$ i z u j ą c az zbawcze działanie Chrystusa wobec nowego Ludu Bożego - Kościoła ${ }^{35}$.

Dlatego też nowy Lud Boży Kościół uważa „obchód misterium paschalnego i jego rozwinięcie w ciągu dni, tygodni i całego roku" za najważniejsze wydarzenie i „istotę kultu chrześcijańskiego" ${ }^{36}$.

Szczytem roku liturgicznego jest święte Triduum Męki i Zmartwychwstania Chrystusa ${ }^{37}$, „ponieważ w czasie niego uobecnia się i dokonuje misterium Paschy, to jest przejścia Pana z tego świata do Ojca" ${ }^{38}$. Święto Paschy Chrystusa, które ma swoje centrum w Wigilii Paschalnej, a jest sprawowane co roku od Mszy wieczornej Wielkiego Czwartku aż do Nieszporów Niedzieli Zmartwychwstania, stanowi centrum roku kościelnego, „ponieważ dzieła odkupienia ludzi i doskonałego uwielbienia Boga Chrystus dokonał przez paschalne misterium swojej błogosławionej Męki, przez które umierając zniweczył naszą śmierć i zmartwychwstając przywrócił nam życie" (ONRLK n.18). Doroczne święta paschalne mają swoje centrum w Wigilii paschalnej, która upamiętnia świętą noc zmartwychwstania Pana i jest „matką wszystkich świętych wigilii" ${ }^{39}$.

„Wigilia paschalna, w którą Izraelici czuwali przez całą noc, oczekując przejścia Pana mającego ich wybawić z niewoli faraona, była przez nich obchodzona jako doroczna pamiątka. Była to figura przyszłej, prawdziwej Paschy Chrystusa, a więc nocy prawdziwego wyzwolenia, w której „Chrystus skruszywszy więzy śmierci, jako zwycięzca wyszedł z otchłani”. Kościół od początku obchodził doroczną Paschę, która jest uroczystością nad uroczystościami, przede wszystkim przez odprawienie nocnej Wigilii. Zmartwychwstanie Chrystusa jest bowiem podstawą naszej wiary i nadziei; przez chrzest i bierzmowanie zostaliśmy wszczepieni w paschalne misterium Chrystusa, z Nim współumarli, współpogrzebani i współzmartwychwstali, razem z Nim też będziemy królować. Wigilia ta jest również oczekiwaniem na powtórne przyjście Pana"40.

${ }^{34}$ Por. J. J a n i c k i, Rok liturgiczny, [w:] Stownik teologiczny. 2., Katowice 1989, 211.

${ }^{35}$ Por. A. J a n k ow s k i, Biblijna teologia..., dz. cyt., 121.

${ }^{36} \mathrm{P}$ a w e 1 VI, Pismo Apostolskie zatwierdzajace ogólne normy roku liturgicznego..., dz. cyt., wstęp.

${ }_{37}$ Ogólne normy roku liturgicznego i kalendarza (=ONRLK), n. 18. n. 38 .

${ }^{38}$ Kongregacja Kultu Bożego, List okólny o przygotowaniu..., dz. cyt.,

${ }^{39}$ Tamże, n. 77.

40 Tamże, nn. 79-80. 
Kościół obchodzi ponadto pięćdziesiąt dni od Niedzieli Zmartwychwstania do Niedzieli Zesłania Ducha Świętego „z wielką radością jako jeden dzień świąteczny, co więcej, jako 'wielką niedzielę' (por. ONRLK, n. 22). Natomiast czterdzieści dni - okres Wielkiego Postu - służy przygotowaniu do obchodu Paschy: „liturgia wielkopostna przygotowuje katechumenów do obchodu paschalnego misterium przez różne stopnie wtajemniczenia chrześcijańskiego, a wiernych przez wspomnienie przyjętego chrztu i pełnienie pokuty" (tamże, n. 27).

Po dorocznym obchodzie misterium paschalnego nic nie jest Kościołowi droższego, jak obchód wspomnienia Narodzenia Pańskiego i Adwentu jako okresu przygotowania do uroczystości Narodzenia Pańskiego (por. ONRLK nn. 32.39).

Tak jak uroczystość Paschy jest szczytem roku liturgicznego, tak niedziela jest szczytem tygodnia. „W pierwszym dniu każdego tygodnia, który nazywa się dniem Pańskim czyli niedzielą, Kościół obchodzi misterium paschalne zgodnie z tradycją apostolską wywodzącą się od samego dnia Zmartwychwstania Chrystusa. Dlatego niedzielę należy uważać za pierwotny dzień świąteczny"41. Sobór Watykański II podał w Konstytucji o liturgii świętej wskazania teologiczne i pastoralne dotyczące przeżywania niedzieli, w których stwierdza, że „zgodnie z tradycją apostolską, która wywodzi się od samego dnia Zmartwychwstania Chrystusa, misterium paschalne Kościół obchodzi co siedem dni, w dniu, który słusznie nazywany jest dniem Pańskim albo niedzielą. W tym dniu wierni powinni schodzić się razem dla słuchania słowa Bożego i uczestniczenia w Eucharystii, aby tak wspominać Mękę, Zmartwychwstanie i chwałę Pana Jezusa i składać dziękczynienie Bogu, który „przez zmartwychwstanie Jezusa Chrystusa na nowo zrodził nas do żywej nadziei" (1 P 1, 3). Niedziela jest zatem najstarszym i pierwszym dniem świątecznym, który należy tak przedstawić i wpoić $w$ pobożność wiernych, aby stał się również dniem radości i odpoczynku od pracy. Ponieważ niedziela jest podstawą i rdzeniem całego roku liturgicznego, nie należy jej przesłaniać innymi obchodami..." (KL 106).

Na kanwie wyżej przypomnianego nauczania Kościoła, czy nie należałoby, przez analogię do Ludu Bożego Starego Przymierza, ciągle na nowo podkreślać zasadnicze dla życia nowego Ludu Bożego Kościoła znaczenie niedzieli - Paschy tygodniowej, jako ustawicznego odnawiania Przymierza, Komunii z Chrystusem Panem, przez którego śmierć i zmartwychwstanie zrodziliśmy się do wspólnoty nowego

${ }^{41}$ ONRLK, n. 4. Tamże, w n.1 znajdujemy m.in. stwierdzenie: „Każdego tygodnia Kościół obchodzi pamiątkę Zmartwychwstania Pańskiego w dniu, który nazywa się Pańskim, a raz do roku czci je razem z jego błogosławioną Męką w największą uroczystość Paschy". 
Ludu Bożego? Opuszczanie niedzielnych zgromadzeń eucharystycznych było od początku uważane w Kościele jako „umniejszanie Ciała Chrystusa”, „lekceważenie i pozbawianie Zbawiciela Jego członków”, „rozrywanie i rozpraszanie Jego Ciała” itp. ${ }^{42}$.

W liturgicznym roku chrześcijańskim także każdy dzień ma swój wymiar paschalny, swoje odniesienie do Paschy Chrystusa, bowiem centrum liturgii każdego dnia stanowi Ofiara eucharystyczna uobecniająca dzieło zbawienia, które dokonało się przez mękę, śmierć i zmartwychwstanie Chrystusa: „ilekroć bowiem sprawujemy pamiątkę Ofiary Chrystusa, spełnia się dzieło naszego odkupienia"43. Każdy dzień jest więc uświęcony przez Ofiarę eucharystyczną, w której głosimy śmierć Chrystusa, wyznajemy Jego zmartwychwstanie i oczekujemy Jego przyjścia w chwale (por. ONRLK, n.3). Każdy dzień jest uświęcony także przez Liturgię godzin, która „najlepiej przygotowuje do owocnego sprawowania Eucharystii i ożywia odpowiednie usposobienie, jak wiarę, nadzieję, miłość, pobożność i ducha ofiary”, bowiem „dzieło odkupienia ludzi i doskonałego uwielbienia Boga... dokonuje się przez Eucharystie i sakramenty, ale także poprzez Liturgię godzin”, „Liturgia godzin uświęca człowieka i wielbi Boga"44.

Teologowie pouczają, że Eucharystia „na zasadzie transpozycji dawnej Paschy jest... radosną anamnezą wyzwolenia nowego Ludu Bożego z groźniejszej niewoli, niż była służba u faraona w Egipcie. W doskonalszym stopniu niż Pascha Izraela Eucharystia jednoczy wewnętrznie ten nowy lud. Św. Paweł, teolog eklezjalnego Ciała Chrystusa, ujmuje w słowach: Chleb, który tamiemy, czyż nie jest udziałem w Ciele Chrystusa? Ponieważ jeden jest chleb, przeto my liczni tworzymy jedno ciato. Wszyscy bowiem bierzemy $z$ tego samego chleba (1 Kor 10, 17).

Podobnie jak dawna Pascha, lecz w stopniu doskonalszym odpowiednio do swego przedmiotu, sprawowanie liturgiczne tej pamiątki stanowi uroczystą proklamację wielkiego zbawczego dzieła - Odkupienia przez śmierć i zmartwychwstanie Chrystusa. (...) Eucharystia jako paschalna nowa pamiątka, ta chrześcijańska anamneza, uobecnia całe misterium Chrystusa, od Wcielenia, które było „ogołoceniem”

${ }^{42}$ Zob. S. C z e r w i k, Teologia Dnia Pańskiego, KPD 60(1984) 198. Popularne u nas stwierdzenie, że oto ktoś „nie chodzi do kościoła” można rozumieć tak jak w podanym tu ujemnym kontekście.

${ }_{43}$ Modlitwa nad darami Mszy Wieczerzy Pańskiej Wielkiego Czwartku (Mszał Rzymski dla diecezji polskich, s. 128). Zob. ponadto art. J. J a$\mathrm{n} \mathrm{i} \mathrm{c} \mathrm{k} \mathrm{i,} \mathrm{Eucharystia} \mathrm{-} \mathrm{centrum} i$ wypetnienie misterium paschalnego, RBL 46(1993) 148-156.

${ }_{44}$ Ogólne wprowadzenie do Liturgii Godzin, nn. 12.13.14. 
poprzez szczyt uniżenia „aż do śmierci krzyżowej”, aż do „przejścia” do chwały Ojca"45.

Jan Paweł II w Liście do wszystkich biskupów Kościola o tajemnicy $i$ kulcie Eucharystii (24.II.1980) poucza, iż „poprzez Sobór uświadomiliśmy sobie $\mathrm{z}$ nową siłą tę odwieczną prawdę, że tak, jak Kościół 'sprawuje Eucharystię', tak 'Eucharystia buduje' Kościół... Kościół został założony jako nowa społeczność Ludu Bożego w apostolskiej wspólnocie tych Dwunastu, którzy podczas Ostatniej Wieczerzy... weszli po raz pierwszy w tę sakramentalną komunię z Synem Bożym, która stanowi zadatek życia wiecznego. Od tego czasu i aż do skończenia wieków, Kościół buduje się poprzez tę samą komunię z Synem Bożym, która jest zadatkiem wiekuistej Paschy" (n. 4).

Nasze rozważania o misterium Paschy jako centrum roku liturgicznego Kościoła - nowego Ludu Bożego wydaje się słusznym zakończyć wskazaniem apostolskiego nauczania Jana Pawła II, które nie może „przejść" nie zauważone:

„Ponieważ śmierć Chrystusa na krzyżu i Jego zmartwychwstanie stanowią treść codziennego życia Kościoła i zapowiedź wiecznej Paschy, pierwszym zadaniem liturgii jest niestrudzone wprowadzanie nas na otwartą przez Chrystusa paschalną drogę, na której człowiek godzi się umrzeć, aby mieć życie wieczne"46.

Kraków

Ks. JAN JÓZEF JANICKI

${ }^{45}$ A. J a n k o w s k i, Eucharystia jako ,nasza Pascha” (1 Kor 5, 7) $w$ teologii biblijnej Nowego Testamentu, RBL 28(1975), $98 \mathrm{n}$.

$46 \mathrm{~J}$ a n P a w e 1 II, List Apostolski $w$ dwudziesta piata rocznice ogtoszenia Konstytucji soborowej „Sacrosanctum Concilium” o świętej liturgii (4.12.1988), n. 6. 